\title{
Design Rainfall Temporal Patterns for Upper Klang Catchment
}

(Date received: 11.4.2018/Date accepted: 4.7.2018)

\author{
Jer Lang Hong1, Azmi Jafri'1, Izihan Ibrahim², Suzana Shafie ${ }^{3}$, Kee An Hong ${ }^{1,5}$ and Irena Naubi ${ }^{3,6}$ \\ ${ }^{1}$ Hong and Associates, ${ }^{2}$ Islamic University Malaysia, ${ }^{3}$ G\&P Water \& Maritime Sdn. Bhd. \\ Email: jerlang.hong@taylors.edu.my, azmijafri@gmail.com²,izihan@gmail.com,izihan@iium.edu.my³, \\ suzana_peace@yahoo.com ${ }^{4}$,keeanhong@yahoo.co.uk ${ }^{5}$,irena.naubi@gmail.com ${ }^{6}$
}

\section{ABSTRACT}

Rainfall temporal patterns are needed as inputs for hydrologic models such as unit hydrograph or runoff routing method used in the derivation of flood hydrographs. The patterns adopted can have a major effect on the resulting flood computed. Short and long duration rainfall data are both required for different sizes of catchments to determine and locate the flood producing critical storms in flood estimation. Design temporal patterns with different durations are therefore also required for distributing the storm rainfall in flood calculations. Patterns for a large number of durations with reasonably short time intervals are needed by designers to reduce the need for interpolation and to maintain the accuracy in obtaining the peak of the hydrograph. In this study, pluviograph data for the Upper Klang Catchment with records of over 30 years are used to derive temporal patterns for 20 standard durations as per ARR87. Rainfall temporal patterns for the upper Klang were derived for rainfall durations from 10 minutes to 72 hours and for time intervals from 5 minutes to 4 hours. The patterns presented in this study demonstrate the use of Average Variability Method in deriving design rainfall temporal patterns for data of the Klang Catchment and the patterns derived can be used for design flood estimations for catchments in the same general region.

\subsection{NEED AND OBJECTIVE}

Rainfall temporal patterns are needed for flood estimation using hydrologic models such as unit hydrograph or runoff routing methods for both rural and urban catchments. The patterns adopted can have a major effect on the resulting flood computed. Examples of differences of up to $50 \%$ in flood peaks from different assumed temporal patterns were given by Askew (1975), Milston (1979) and Cordery et al., (1984). With the data used in developing temporal patterns in Australian rainfall and runoff (ARR87), analysis on several catchments showed that computed flood peaks varied by as much as 2.5 times for extreme patterns in individual observed heavy rainfalls. It has been shown by Askew (1975) and Cordery et al., (1984) that the critical duration of design rainfall is also dependent on the temporal pattern.

In flood estimation, short and long duration rainfall data are both required for different sizes of catchments to determine and locate the flood producing critical storms. Design temporal patterns with different durations are therefore also required for distributing the storm rainfall in flood calculations. Patterns for a large number of durations with reasonably short time intervals are needed by designers to reduce the need for interpolation and to maintain the accuracy in obtaining the peak of the hydrograph.

In design, an average temporal pattern is generally used which is derived from a large number of rainfall stations in a region. Examples are the SCS method (1973) which consists of 24 hour and 6 hour distributions for use in developing runoff hydrographs. Hershfield (1962) developed an average time distribution using rainfall data from 50 widely separated situations for durations of 6, 12, 18 and 24 hours. Huff (1967) presented the time distribution of rainfall using 11 years of data from 49 gauges in Illinois. Keifer and Chu (1957) introduced the Chicago method for use in Sewer design. This method is based on the intensity duration curves with specific return period. Yen and Chow (1980) applied the method of statistical moments to describe rainfall distribution. This is the triangular hyetograph.

The composite method is established by utilizing depth duration data directly. For a specific return period, maximum depth values for successively larger durations are obtained. Incremental depth and corresponding incremental durations are computed and average incremental intensities are calculated for each of the incremental durations. The resulting intensities are then rearranged in an arbitrary sequence to form the design temporal pattern. Pilgrim and Cordery (1975) developed a method for developing design temporal patterns based on an analysis which retains the identity of the events. This Average Variability Method has been recommended to derive design rainfall hyetograph (Ball, 1994). The Average Variability Method has been used to derive rainfall temporal pattern for Australia (ARR87). Touhid et al., (2010) applied the ARR87 method to derive the 96 and 120 hour rainfall temporal patterns for Gold Coast region in Australia. The method has also been applied by Rahman et al., (2006) to investigate the design rainfall temporal pattern in Queensland.

Temporal patterns have been developed in Hydrological Procedure No. 1 by simple averaging of storm rainfall (DID, 1982) and these have been used in flood estimation for catchments in Peninsular Malaysia. Long-time intervals were used in these patterns and these may result in calculated discharge missing the peak of the hydrograph. There are only a limited number of patterns available in the Procedure and interpolation is required to obtain intermediate patterns. As pluviograph rainfall data have been increased by a large amount for the past 20 years, it is the aim of this study to derive design rainfall temporal patterns for Upper Klang Catchment using the local data and employing the widely accepted Method of Average Variability as used in ARR87. 
Table 1: Duration and Time Interval Used to Derive Rainfall Pattern

\begin{tabular}{|c|c|c|c|c|c|}
\hline No. & $\begin{array}{c}\text { Storm } \\
\text { Duration, } \\
\text { Minutes } \\
\text { (Hrs) }\end{array}$ & $\begin{array}{c}\text { Time } \\
\text { Interval, } \\
\text { Minutes (Hrs) }\end{array}$ & No. & $\begin{array}{c}\text { Storm } \\
\text { Duration, } \\
\text { Minutes } \\
\text { (Hrs) }\end{array}$ & $\begin{array}{c}\text { Time } \\
\text { Interval, } \\
\text { Minutes } \\
\text { (Hrs) }\end{array}$ \\
\hline 1. & 10 & 5 & 11. & $(4.5)$ & 15 \\
\hline 2. & 15 & 5 & 12. & $(6)$ & 30 \\
\hline 3. & 20 & 5 & 13. & $(9)$ & 30 \\
\hline 4. & 25 & 5 & 14. & $(12)$ & 30 \\
\hline 5. & 30 & 5 & 15. & $(18)$ & $(1)$ \\
\hline 6. & 45 & 5 & 16. & $(24)$ & $(1)$ \\
\hline 7. & $(1)$ & 5 & 17. & $(30)$ & $(2)$ \\
\hline 8. & $(1.5)$ & 5 & 18. & $(36)$ & $(2)$ \\
\hline 9. & $(2)$ & 5 & 19. & $(48)$ & $(2)$ \\
\hline 10. & $(3)$ & 15 & 20. & $(72)$ & $(4)$ \\
\hline
\end{tabular}

Recently, researches in Australia on the development of a holistic approach of design flood estimation using probability distributed inputs including temporal pattern e.g. Rahman et al., (2002) and Nathan and Weinmann (2004). However, it will take some time to develop design data and application tools for these new approach that can be used in the water industry. The NOAA method (2014) is similar to the one developed by Huff (1967) except in the definition of rainfall cases. Rainfall cases for the temporal distribution analysis were selected from the annual maximum series used in the rainfall frequency analysis. Each case (i.e. maxima) was the total accumulation over a selected duration (e.g. 1, 6, 12, 24 hour). Therefore, the rainfall cases for this analysis may contain parts of one or more storms. Because of this, temporal distribution curves presented will be different from corresponding temporal distribution curves obtained from the analysis of single storms.

In general, flood estimations are based on design event approach as recommended in ARR87. This method needs the formulation of a design rainfall event and use of a rainfall runoff model to convert the design rainfall event into the corresponding design flow. The design rainfall event is specified by the rainfall duration, average rainfall intensity of a particular average recurrence interval (ARI) and the rainfall temporal pattern. The main assumption of the design event approach is that a rainfall intensity of a particular ARI can be converted to a streamflow hydrograph peak of the same ARI using critical duration and representative values of other input variables to the rainfall runoff model such as initial loss. The ARR87 adopted such a concept for deriving the rainfall temporal patterns for use in Australia. The patterns derived are assumed to provide the conversion of a $Y$ year rainfall to a design flood of the same ARI.

In this study, pluviograph data for the Upper Klang Catchment with records of over 30 years are used to derive temporal patterns for 20 standard durations as per ARR87 as shown in Table 1.

The patterns presented in this study demonstrate the use of Average Variability Method in deriving design rainfall temporal patterns for data of the Klang Catchment and the patterns derived can be used for design flood estimations for catchments in the same general region.

\subsection{DATA}

Pluviograph data from the Klang Basin were examined and data for 4 stations were adopted for this study based on a number of criteria. It is important that the region where the temporal patterns are to be derived should consist a reasonable number of pluviograph stations with long record lengths so that the final design temporal patterns are statistically meaningful. The selected pluviograph stations must be separated by a minimum distance to satisfy spatial independence. A study by Faridah et al., (2011) for the Klang Basin showed that the effective range of influence is $6.27 \mathrm{~km}$ for two rainfall stations. Study by Rahman et al., (2006) for Gold Coast region in Australia indicates that a minimum distance of $7 \mathrm{~km}$ showed insignificant correlations between rainfalls of two stations. Based on the above findings, a minimum distance of $7 \mathrm{~km}$ between stations was considered appropriate for this study.

Table 2: Details of rainfall station

\begin{tabular}{|c|l|c|}
\hline $\begin{array}{c}\text { Station } \\
\text { number }\end{array}$ & \multicolumn{1}{|c|}{ Station name } & $\begin{array}{c}\text { Years of } \\
\text { Record }\end{array}$ \\
\hline 3216001 & Kg. Sg. Tua & 27 \\
\hline 3217001 & Ibu Bekalan KM 16, Gombak & 27 \\
\hline 3317004 & Genting Sempah & 27 \\
\hline 3117070 & Pusat Penyelidikan di JPS Ampang & 30 \\
\hline
\end{tabular}

A thorough search shows that 4 pluviograph stations, which are evenly distributed in the upper reach of Sg. Klang, are most suitable for the use in this study. The locations of these stations are shown in Figure 1. Details of the stations are presented in Table 2.

Pluviograph data for these stations are obtained from JPS, Ampang and were checked for consistency and completeness for this study.

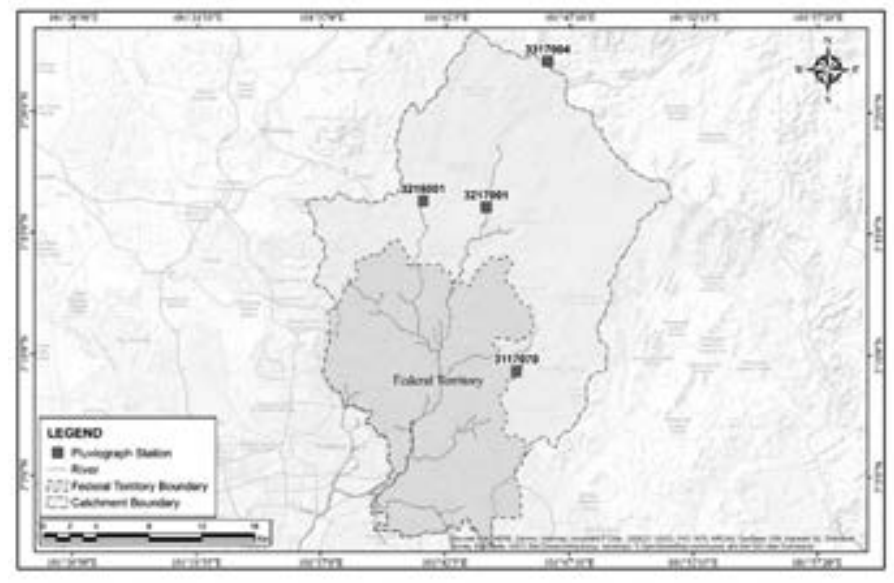

Figure 1: Locations of pluviograph stations

\subsection{METHODOLOGY}

The Method of Average Variability is best explained using an example given by Pilgrim et al., (1969). Table 3 shows the first 10 ranked storms of 20 minutes duration, each of these storms is separated into four 5 minutes periods. Burst 1 has $32 \mathrm{~mm}, 48 \mathrm{~mm}$, $48 \mathrm{~mm}$ and $48 \mathrm{~mm}$ rainfalls in periods $1,2,3$ and 4 respectively. The rank of each period is given in the next 4 columns i.e. columns 8 to 11 and the percentage of rainfall in each period is given in the next 4 columns, from columns 12 to 15 . If the 
Table 3: Method of Average Variability (Pilgrim et al., 1969)

\begin{tabular}{|c|c|c|c|c|c|c|c|c|c|c|c|c|c|c|}
\hline 1 & 2 & 3 & 4 & 5 & 6 & 7 & 8 & 9 & 10 & 11 & 12 & 13 & 14 & 15 \\
\hline Date & $\begin{array}{c}\text { Rain in } \\
\text { mm }\end{array}$ & Rank & \multicolumn{4}{|c|}{$\begin{array}{c}\text { Rain in each period } \\
\text { Period }\end{array}$} & \multicolumn{4}{|c|}{$\begin{array}{c}\text { Rank of each period's rain } \\
\text { Period }\end{array}$} & \multicolumn{4}{|c|}{$\begin{array}{c}\% \text { of rain in period of each } \\
\text { rank }\end{array}$} \\
\hline & & & 1 & 2 & 3 & 4 & 1 & 2 & 3 & 4 & 1 & 2 & 3 & 4 \\
\hline 20.11 .32 & 176 & 1 & 32 & 48 & 48 & 48 & 4 & 2 & 2 & 2 & 27 & 27 & 27 & 18 \\
\hline 20.03 .14 & 168 & 2 & 30 & 44 & 44 & 50 & 4 & 2.5 & 2.5 & 1 & 30 & 26 & 26 & 18 \\
\hline 29.09 .43 & 166 & 3 & 48 & 46 & 31 & 41 & 1 & 2 & 4 & 3 & 29 & 28 & 25 & 19 \\
\hline 26.10 .22 & 157 & 4 & 42 & 65 & 35 & 15 & 2 & 1 & 3 & 4 & 41 & 27 & 22 & 10 \\
\hline 09.03 .15 & 153 & 5 & 18 & 50 & 45 & 40 & 4 & 1 & 2 & 3 & 33 & 29 & 26 & 12 \\
\hline 25.10 .19 & 150 & 6 & 40 & 27 & 41 & 42 & 3 & 4 & 2 & 1 & 28 & 27 & 27 & 18 \\
\hline 20.11 .61 & 140 & 7 & 35 & 35 & 35 & 35 & 2.5 & 2.5 & 2.5 & 2.5 & 25 & 25 & 25 & 25 \\
\hline 19.01 .26 & 139 & 8 & 36 & 48 & 40 & 15 & 3 & 1 & 2 & 4 & 35 & 29 & 26 & 11 \\
\hline 25.09 .51 & 137 & 9 & 44 & 20 & 37 & 36 & 1 & 4 & 2 & 3 & 32 & 27 & 26 & 15 \\
\hline 15.06 .49 & 133 & 10 & 42 & 40 & 35 & 16 & 1 & 2 & 3 & 4 & 32 & 30 & 26 & 11 \\
\hline & & & \multicolumn{4}{|c|}{ Average } & 2.55 & 2.2 & 2.5 & 2.75 & 31 & 27 & 26 & 16 \\
\hline & & & \multicolumn{4}{|c|}{ Standard deviation } & 1.25 & 1.11 & 0.66 & 1.13 & 4.6 & 1.5 & 1.4 & 4.8 \\
\hline & & & \multicolumn{4}{|c|}{ Assigned rank } & 3 & 1 & 2 & 4 & & & & \\
\hline & & & \multicolumn{4}{|c|}{ Period } & 1 & 2 & 3 & 4 & & & & \\
\hline & & & \multicolumn{4}{|c|}{ Final pattern (\% of total rainfall) } & 26 & 31 & 27 & 16 & & & & \\
\hline
\end{tabular}

rainfall amount is the same over more than 1 period, an average rank is assigned, as shown for storms 1,2 and 7. An average rank is obtained for each period, e.g. 2.55, 2.2, 2.5 and 2.75 for periods 1, 2, 3 and 4, respectively in Table 3. These average values are then ranked, e.g. 2.55, 2.5, 2.2 and 2.75 are given ranks 3, 2, 1 and 4 respectively, and they are termed "assigned rank".

In columns 12 to 15 , the percentages of rainfall in the various periods are listed in order of magnitude. For a given duration, the average variation from a uniform burst is found by averaging the percentages of rainfall in the most intense period of each of the ranked bursts, then in the second most intense period, and so on. This is done by averaging the percentages of rainfall listed in columns 12 to 15 in Table 3 , the average rainfall in the heaviest period is $31 \%$ of the total rainfall. The Method of Average Variabilty assumes that these average percentages of rainfalls are reasonable estimates of the percentages that would occur in the period of the burst of rainfall of average variability. It is considered that the most intense rainfall within the storm should be assigned to the period whose average rank is the lowest. Similarly, the second most intense rainfall is assigned to the period whose average rank is the second lowest and so on. Thus, the design temporal patterns of the 20 minutes rainfall burst derived from the 10 most intense 20 minutes duration bursts with four 5 minutes periods are $26 \%, 31 \%, 27 \%$ and $16 \%$ respectively.

A computer program was developed for computing the design rainfall temporal patterns using the Method of Average Variability. Data for each storm duration with specific intervals were extracted from JPS data bank using the TIDEDA program of JPS. The TIDEDA program is able to extract the maximum rainfall, either the partial or annual series for each rainfall station for any rainfall duration. The rainfall total in a specified interval for the duration can also be printed.

\subsection{STORM BURST PARTIAL SERIES}

For each station, the $\mathrm{n}$ highest rainfall totals were obtained for each of the 20 durations of storm burst, where $n$ is the number of years of record for a particular rainfall station, each of the 20 storms was then subdivided into a number of equal time intervals or periods, ranging from 5 minutes for short duration storms to 4 hours for the 72 hour storm. These form the partial series storm events for each rainfall station. Adequate durations and time intervals for the storms were chosen so that the response times of actual catchments can be properly modeled when a rainfall runoff method is used.

The rainfall total chosen should be sufficiently large for the event to be one of the $n$ largest values for the particular duration from $n$ years of record. The storm burst should be independent so that there is no overlapping in time of successive storms. The rain did not have to persist for the entire length of specified duration, in this case the storm burst duration begins when the rain begins. There can be little or no rain in the later periods of the storm bursts.

\subsection{RESULTS}

\subsection{Mean Temporal Distributions}

In order to derive the average temporal distribution of rainfall for each duration in the study area, the partial series of the storm burst samples from all the stations were combined to form a regional partial series. The Method of Average Variability is then used to derive the mean temporal patterns for each storm duration. These temporal patterns are called raw rainfall temporal patterns.

\subsection{Temporal Patterns for ARI $\leq 30$ Years}

As noted, the highest intensities may occur in the first time period in many patterns. In these cases, the computed hydrographs using the patterns are very sensitive to the normally assumed initial 


\section{DESIGN RAINFALL TEMPORAL PATTERNS FOR UPPER KLANG CATCHMENT}

loss. To reduce the effect of the loss assumed, the percentage values in the first two periods were interchanged in some cases for storm durations less than 24 hours.

The other problem encountered is that when a pattern of a particular duration was applied to the average rainfall intensity for that duration derived from intensity-duration-frequency analysis, the intensities for various shorter periods within the pattern were greater than the average intensities derived from frequency intensity duration analysis for some cases for durations equal to these shorter periods. For such cases, a mathematical filtering procedure was adopted to ensure that the sub-duration (or period) rainfall does not exceed the corresponding rainfall for the same shorter period by an excessive amount at an ARI of 20 years. Generally, the allowable excess was set at $10 \%$, but in few cases this was increased to $20 \%$ to prevent undue distortion of the derived patterns. This was tested at 3 out of 4 points for the Upper Klang Basin. A set of rainfall intensity-frequencyduration data was prepared for each of the 20 standard durations at each of the 3 stations chosen. The 20 year rainfall was then calculated for each of the 20 durations for these pluviograph stations. These values were then used to test the sub-duration consistency of the raw temporal patterns.

The newly derived temporal patterns are used to disaggregate the design rainfalls for various durations. Short duration rainfall values which were obtained using the newly derived temporal patterns, are used to obtain long duration rainfall values. If these values differ by more than $10 \%$ from the design rainfall from intensity-duration-frequency analysis, the design temporal patterns are smoothed by trial and error by adjusting the newly derived patterns to bring the differences within $10 \%$ across all the durations for all the selected stations in the study area. This was achieved by reducing the percentage values in the peak and adjacent periods and redistributing the amount of this reduction to the remaining periods of the pattern. Figure 2 shows the filtering procedures. For example, for a pattern with 4 periods, the rainfall intensity from the intensity duration frequency curve is compared with the rainfall obtained from the temporal pattern with the highest percentage (period 2) considering the total rainfall derived from IDF analysis for the duration of the

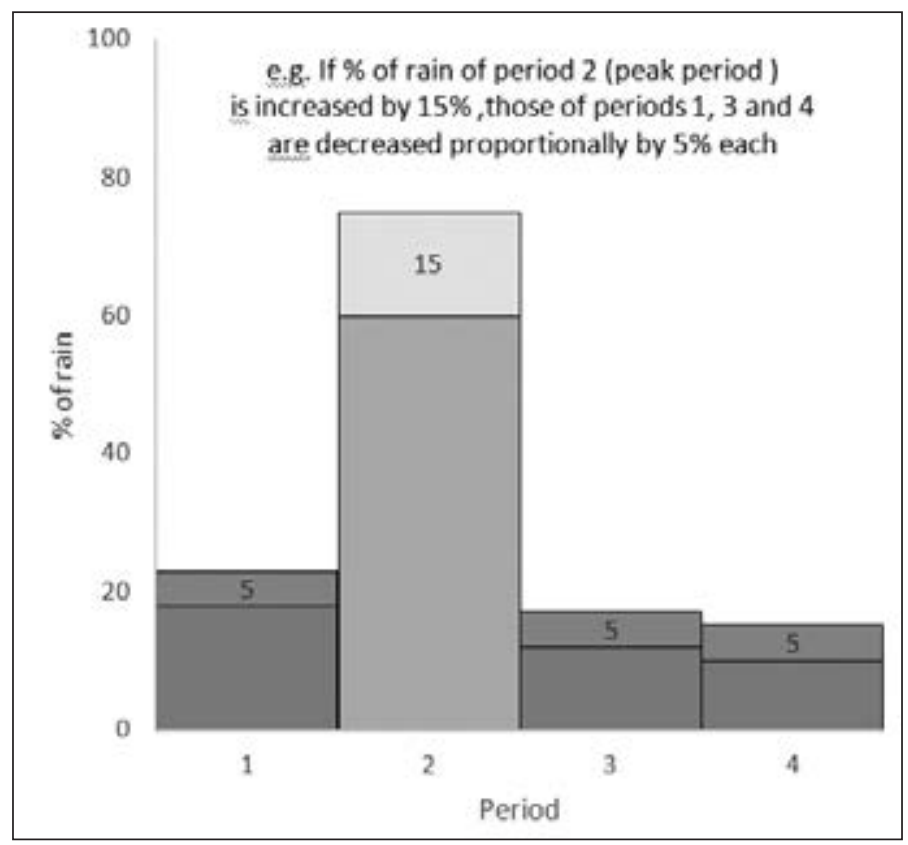

Figure 2: Mathematical filtering process storm (4 periods), if the rainfall computed from temporal pattern percentage is lower than that from IDF analysis, an amount equal to $90 \%$ of the difference between them is to be added to this period to make the difference fall below $10 \%$. As the increase in percentage rainfall in this period will increase the total percentage rainfall for the total storm, the percentage values of the remaining periods are decreased proportionally so that the total percentage will add up to 100. This is done for 2 periods, 3 periods and so on. The final temporal patterns for ARI $\leq 30$ years are shown in Table 4.

\subsection{Temporal Patterns for ARI > 30 Years}

To derive temporal patterns for ARI > 30 years, the highest 15 $\%$ of the bursts based on the rainfall intensity were used for each of the 20 durations for the 4 selected stations. This was done by taking the highest $15 \%$ of the storm bursts in each station partial series and combining them into areal samples representing the highest $15 \%$ of the storm bursts. This method of selecting the storm bursts from the station series avoids bias in choosing samples from rainfall station which has heavier rainfall. The higher ranked percentages i.e. ranks 1, 2 etc. for the patterns of ARI $>30$ years were found to be generally smaller than those of ARI $\leq 30$ years of the same ranks. This showed that rainfall distributions are more uniform for more severe, less frequent storms than the more peaked distributions of less severe, more frequent storms. These findings are consistent with the studies of ARR87 (1987) and Rahman et al., (2006).

The consistency between rainfall temporal patterns $>30$ years and those $\leq 30$ years was checked by adopting the procedure of ARR87. The ratio between the percentage values of each rank of the greater than 30 years ARI temporal patterns and the percentage values of the corresponding rank of patterns of ARI $\leq 30$ years was calculated. This was done for 14 out of 20 durations from 1 to 72 hours. The average ratios for the periods are then plotted against their respective ranking positions and a smooth curve is fitted with all the data as shown in Figure 3. The smooth curve is used to find the ratio for factoring the percentage values of the mean temporal patterns. The adopted ratios for ranking position from 1 to 24 are $0.94,0.96,0.98,1.00$, $1.02,1.03,1.04,1.06,1.08,1.10,1.12,1.14,1.15,1.17,1.19$, $1.21,1.23,1.24,1.26,1.28,1.29,1.31,1.33$ and 1.35 .

The percentage values for patterns $\leq 30$ years were factored by the ratios derived to obtain temporal patterns $>30$ years. The procedure was used to derive the patterns for all the 20 durations.

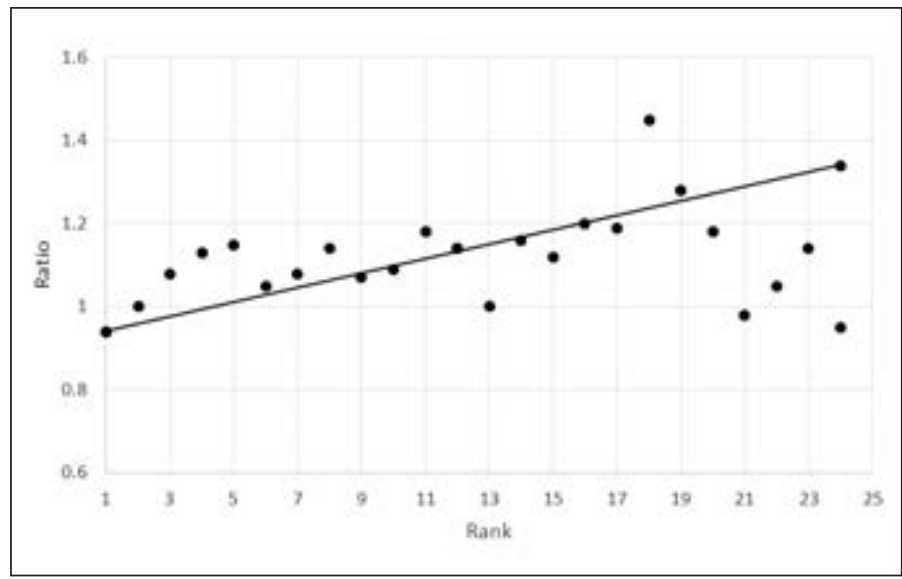

Figure 3: Ratio of percentage values of $A R I>30$ years and $A R I \leq 30$ years 
STORM DURATION: 10 MINS

ARI $\leq 30$ YEARS

Period of design storm, $\mathrm{P}$

$\%$ of total rainfall

\begin{tabular}{|c|c|c}
\hline 1 & 2 \\
\hline 11.1 & 88.9
\end{tabular}

ARI > 30 YEARS

Period of design storm, $\mathrm{P}$

$\%$ of total rainfall

\begin{tabular}{|c|c}
\hline 1 & 2 \\
\hline 16.4 & 83.6 \\
\hline
\end{tabular}

STORM DURATION: 15 MINS

ARI $\leq 30$ YEARS

Period of design storm, $\mathrm{P}$

$\%$ of total rainfall

\begin{tabular}{|c|c|c|}
\hline 1 & 2 & 3 \\
\hline 11.2 & 84.4 & 4.4 \\
\hline
\end{tabular}

ARI > 30 YEARS

Period of design storm, $\mathrm{P}$

$\%$ of total rainfall

\begin{tabular}{|c|c|}
\hline 1 & 2 \\
\hline 14.8 & 79.3 \\
\hline
\end{tabular}

3

79.3

\section{STORM DURATION: 20 MINS}

ARI $\leq 30$ YEARS

Period of design storm, $\mathrm{P}$

$\%$ of total rainfall

\begin{tabular}{|c|c|}
\hline 1 & 2 \\
\hline 12.1 & 77.2 \\
\hline
\end{tabular}

\begin{tabular}{|c|c|}
\hline 3 \\
7.4
\end{tabular}

4

ARI > 30 YEARS

Period of design storm, $\mathrm{P}$

$\%$ of total rainfall

\begin{tabular}{|c|c|}
\hline 1 & 2 \\
\hline 14.4 & 72.6 \\
\hline
\end{tabular}

\begin{tabular}{|c|c|}
3 \\
9.0
\end{tabular}

4

STORM DURATION: 25 MINS

ARI $\leq 30$ YEARS

Period of design storm, $\mathrm{P}$

$\%$ of total rainfall

\begin{tabular}{|c|c|c|}
\hline 1 & 2 \\
\hline 13.0 & 68.7 \\
\hline
\end{tabular}

\begin{tabular}{|c|c|}
\hline 3 \\
7.9
\end{tabular}

\begin{tabular}{|c|c|}
\hline 4 & 5 \\
\hline 3.5 & 6.9 \\
\hline
\end{tabular}

ARI > 30 YEARS

Period of design storm, $\mathrm{P}$

$\%$ of total rainfall

\begin{tabular}{|c|c|}
\hline 1 & 2 \\
\hline 12.6 & 64.6 \\
\hline
\end{tabular}

\begin{tabular}{|c|c|}
\hline 3 \\
9.7
\end{tabular}

\begin{tabular}{|c|c|}
\hline 4 & 5 \\
\hline 4.5 & 8.7 \\
\hline
\end{tabular}

STORM DURATION: 30 MINS

ARI $\leq 30$ YEARS

Period of design storm, $\mathrm{P}$

$\%$ of total rainfall

\begin{tabular}{|c|}
1 \\
13.8
\end{tabular}

\begin{tabular}{|r}
2 \\
60
\end{tabular}

ARI > 30 YEARS

Period of design storm, $\mathrm{P}$

$\%$ of total rainfall

\begin{tabular}{|c|c|c|c|c|c|}
\hline 1 & 2 & 3 & 4 & 5 & 6 \\
\hline 13.3 & 57.7 & 5.5 & 8.5 & 6.8 & 8.7 \\
\hline
\end{tabular}

\section{STORM DURATION: 45 MINS}

ARI $\leq 30$ YEARS

Period of design storm, $\mathrm{P}$

$\%$ of total rainfall

\begin{tabular}{|c|c|c|c|c|c|c|c|c|}
\hline 1 & 2 & 3 & 4 & 5 & 6 & 7 & 8 & 9 \\
\hline 3.1 & 12.6 & 51.4 & 5.6 & 3.7 & 7.8 & 5.2 & 4.2 & 6.4 \\
\hline
\end{tabular}

ARI > 30 YEARS

Period of design storm, $\mathrm{P}$

$\%$ of total rainfall

\begin{tabular}{|c|c|c|c|c|c|c|c|c|}
\hline 1 & 2 & 3 & 4 & 5 & 6 & 7 & 8 & 9 \\
\hline 3.7 & 12.1 & 48.4 & 6.3 & 4.3 & 7.6 & 5.9 & 4.8 & 6.9 \\
\hline
\end{tabular}


STORM DURATION: 1 HOUR

ARI $\leq 30$ YEARS

Period of design storm, $\mathrm{P}$

$\%$ of total rainfall

\begin{tabular}{|c|c|c|c|c|c|c|c|c|c|c|c|}
\hline 1 & 2 & 3 & 4 & 5 & 6 & 7 & 8 & 9 & 10 & 11 & 12 \\
\hline 4.3 & 3.6 & 4.5 & 1.3 & 45.9 & 2.7 & 7.3 & 6.2 & 5.2 & 3.6 & 2.4 & 3.0 \\
\hline
\end{tabular}

ARI > 30 YEARS

Period of design storm, $\mathrm{P}$

$\%$ of total rainfall

\begin{tabular}{|c|c|c|c|c|c|c|c|c|c|c|c|}
\hline 1 & 2 & 3 & 4 & 5 & 6 & 7 & 8 & 9 & 10 & 11 & 12 \\
\hline 4.7 & 4.1 & 4.9 & 10.9 & 43.2 & 3.2 & 7.2 & 6.2 & 5.6 & 4.0 & 2.9 & 3.1 \\
\hline
\end{tabular}

STORM DURATION: 1.5 HOURS

ARI $\leq 30$ YEARS

\begin{tabular}{|l|c|c|c|c|c|c|c|c|c|c|c|c|c|c|}
\hline Period of design storm, P & 1 & 2 & 3 & 4 & 5 & 6 & 7 & 8 & 9 & 10 & 11 & 12 \\
\hline \% of total rainfall & 2.7 & 4.7 & 3.5 & 3.8 & 7.4 & 4.5 & 39.2 & 7.8 & 4.8 & 4.1 & 4.0 & 3.0 \\
\hline Period of design storm, P & 13 & 14 & 15 & 16 & 17 & 18 & \\
\cline { 1 - 2 } & 2.4 & 2.2 & 1.9 & 1.6 & 1.1 & 1.3 & \\
\end{tabular}

ARI > 30 YEARS

\begin{tabular}{|c|c|c|c|c|c|c|c|c|c|c|c|c|}
\hline Period of design storm, $\mathrm{P}$ & 1 & 2 & 3 & 4 & 5 & 6 & 7 & 8 & 9 & 10 & 11 & 12 \\
\hline$\%$ of total rainfall & 3.0 & 4.8 & 3.7 & 4.0 & 7.3 & 4.6 & 36.8 & 7.5 & 4.8 & 4.1 & 4.1 & 3.2 \\
\hline Period of design storm, $\mathrm{P}$ & 13 & 14 & 15 & 16 & 17 & 18 & & & & & & \\
\hline$\%$ of total rainfall & 2.7 & 2.5 & 2.2 & 1.9 & 1.3 & 1.5 & & & & & & \\
\hline
\end{tabular}

STORM DURATION: 2 HOURS

ARI $\leq 30$ YEARS

Period of design storm, $\mathrm{P}$

$\%$ of total rainfall

Period of design storm, $\mathrm{P}$

$\%$ of total rainfall

\begin{tabular}{|c|c|c|c|c|c|c|c|c|c|c|c|}
\hline 1 & 2 & 3 & 4 & 5 & 6 & 7 & 8 & 9 & 10 & 11 & 12 \\
\hline 2.0 & 3.1 & 3.5 & 4.9 & 5.4 & 3.3 & 7.3 & 34.6 & 4.9 & 2.5 & 5.3 & 4.0 \\
\hline 13 & 14 & 15 & 16 & 17 & 18 & 19 & 20 & 21 & 22 & 23 & 24 \\
\hline 2.9 & 2.6 & 2.4 & 2.2 & 1.8 & 1.6 & 1.5 & 1.2 & 1.1 & 0.8 & 0.5 & 0.6 \\
\hline
\end{tabular}

ARI > 30 YEARS

Period of design storm, $P$

$\%$ of total rainfall

Period of design storm, $\mathrm{P}$

$\%$ of total rainfall

\begin{tabular}{|c|c|c|c|c|c|c|c|c|c|c|c|}
\hline 1 & 2 & 3 & 4 & 5 & 6 & 7 & 8 & 9 & 10 & 11 & 12 \\
\hline 2.2 & 3.1 & 3.7 & 5.0 & 5.3 & 3.2 & 7.0 & 32.5 & 5.0 & 2.6 & 5.3 & 4.1 \\
\hline 13 & 14 & 15 & 16 & 17 & 18 & 19 & 20 & 21 & 22 & 23 & 24 \\
\hline 2.9 & 2.7 & 2.5 & 2.3 & 2.0 & 1.8 & 1.7 & 1.4 & 1.3 & 1.1 & 0.6 & 0.7 \\
\hline
\end{tabular}

STORM DURATION: 3 HOURS

ARI $\leq 30$ YEARS

Period of design storm, $\mathrm{P}$

$\%$ of total rainfall

\begin{tabular}{|c|c|c|c|c|c|c|c|c|c|c|c|}
\hline 1 & 2 & 3 & 4 & 5 & 6 & 7 & 8 & 9 & 10 & 11 & 12 \\
\hline 2.4 & 6.6 & 16.7 & 41.4 & 12.5 & 9.1 & 4.9 & 3.7 & 1.6 & 0.8 & 0.2 & 0.1 \\
\hline
\end{tabular}

ARI > 30 YEARS

Period of design storm, $\mathrm{P}$

$\%$ of total rainfall

\begin{tabular}{|c|c|c|c|c|c|c|c|c|c|c|c|}
\hline 1 & 2 & 3 & 4 & 5 & 6 & 7 & 8 & 9 & 10 & 11 & 12 \\
\hline 2.8 & 7.5 & 16.0 & 38.9 & 12.3 & 9.1 & 5.7 & 4.4 & 1.9 & 1.0 & 0.3 & 1.0 \\
\hline
\end{tabular}

STORM DURATION: 4.5 HOURS

ARI $\leq 30$ YEARS

\begin{tabular}{|c|c|c|c|c|c|c|c|c|c|c|c|c|}
\hline Period of design storm, $\mathrm{P}$ & 1 & 2 & 3 & 4 & 5 & 6 & 7 & 8 & 9 & 10 & 11 & 12 \\
\hline$\%$ of total rainfall & 2.6 & 36.8 & 11.3 & 15.5 & 9.1 & 5.9 & 5.4 & 3.3 & 3.3 & 1.6 & 2.0 & 1.0 \\
\hline Period of design storm, $\mathrm{P}$ & 13 & 14 & 15 & 16 & 17 & 18 & & & & & & \\
\hline$\%$ of total rainfall & 0.8 & 0.5 & 0.3 & 0.2 & 0.2 & 0.2 & & & & & & \\
\hline
\end{tabular}

ARI > 30 YEARS

\begin{tabular}{|c|c|c|c|c|c|c|c|c|c|c|c|c|}
\hline Period of design storm, $\mathrm{P}$ & 1 & 2 & 3 & 4 & 5 & 6 & 7 & 8 & 9 & 10 & 11 & 12 \\
\hline$\%$ of total rainfall & 3.0 & 34.6 & 11.1 & 14.9 & 9.1 & 6.0 & 5.6 & 3.7 & 3.8 & 1.9 & 2.4 & 1.2 \\
\hline Period of design storm, $\mathrm{P}$ & 13 & 14 & 15 & 16 & 17 & 18 & & & & & & \\
\hline$\%$ of total rainfall & 1.0 & 0.6 & 0.3 & 0.3 & 0.3 & 0.2 & & & & & & \\
\hline
\end{tabular}




\section{STORM DURATION: 6 HOURS}

ARI $\leq 30$ YEARS

Period of design storm, $\mathrm{P}$

$\%$ of total rainfall

\begin{tabular}{|c|c|c|c|c|c|c|c|c|c|c|c|}
\hline 1 & 2 & 3 & 4 & 5 & 6 & 7 & 8 & 9 & 10 & 11 & 12 \\
\hline 4.7 & 43.9 & 26.6 & 12.3 & 7.6 & 2.9 & 1.1 & 0.5 & 0.1 & 0.1 & 0.1 & 0.1 \\
\hline
\end{tabular}

ARI > 30 YEARS

Period of design storm, $\mathrm{P}$

$\%$ of total rainfall

\begin{tabular}{|c|c|c|c|c|c|c|c|c|c|c|c|}
\hline 1 & 2 & 3 & 4 & 5 & 6 & 7 & 8 & 9 & 10 & 11 & 12 \\
\hline 6.6 & 41.3 & 25.5 & 12.1 & 7.6 & 4.1 & 1.6 & 0.7 & 0.1 & 0.2 & 0.1 & 0.1 \\
\hline
\end{tabular}

STORM DURATION: 9 HOURS

ARI $\leq 30$ YEARS

Period of design storm, $\mathrm{P}$

$\%$ of total rainfall

Period of design storm, $\mathrm{P}$

$\%$ of total rainfall

\begin{tabular}{|c|c|c|c|c|c|c|c|c|c|c|c|}
\hline 1 & 2 & 3 & 4 & 5 & 6 & 7 & 8 & 9 & 10 & 11 & 12 \\
\hline 7.4 & 43.3 & 26.2 & 11.3 & 4.6 & 2.9 & 1.7 & 1.0 & 0.6 & 0.2 & 0.1 & 0.1 \\
\hline 13 & 14 & 15 & 16 & 17 & 18 & & & & & & \\
\hline 0.1 & 0.1 & 0.1 & 0.1 & 0.1 & 0.1 & & & & & & \\
\hline
\end{tabular}

ARI > 30 YEARS

Period of design storm, $P$

$\%$ of total rainfall

Period of design storm, $\mathrm{P}$

$\%$ of total rainfall

\begin{tabular}{|c|c|c|c|c|c|c|c|c|c|c|c|}
\hline 1 & 2 & 3 & 4 & 5 & 6 & 7 & 8 & 9 & 10 & 11 & 12 \\
\hline 7.4 & 40.7 & 25.2 & 11.1 & 4.7 & 3.0 & 3.1 & 1.8 & 1.1 & 0.3 & 0.2 & 0.2 \\
\hline 13 & 14 & 15 & 16 & 17 & 18 & & & & & & \\
\hline 0.2 & 0.2 & 0.2 & 0.2 & 0.2 & 0.2 & & & & & & \\
\hline
\end{tabular}

STORM DURATION: 12 HOURS

ARI $\leq 30$ YEARS

\begin{tabular}{|c|c|c|c|c|c|c|c|c|c|c|c|c|}
\hline Period of design storm, $\mathrm{P}$ & 1 & 2 & 3 & 4 & 5 & 6 & 7 & 8 & 9 & 10 & 11 & 12 \\
\hline$\%$ of total rainfall & 22.4 & 37.4 & 13.3 & 8.6 & 5.6 & 3.8 & 2.7 & 1.9 & 1.4 & 0.9 & 0.5 & 0.1 \\
\hline Period of design storm, $\mathrm{P}$ & 13 & 14 & 15 & 16 & 17 & 18 & 19 & 20 & 21 & 22 & 23 & 24 \\
\hline$\%$ of total rainfall & 0.3 & 0.1 & 0.1 & 0.1 & 0.1 & 0.1 & 0.1 & 0.1 & 0.1 & 0.1 & 0.1 & 0.1 \\
\hline
\end{tabular}

ARI > 30 YEARS

Period of design storm, $\mathrm{P}$

$\%$ of total rainfall

Period of design storm, $\mathrm{P}$

$\%$ of total rainfall

\begin{tabular}{|c|c|c|c|c|c|c|c|c|c|c|c|}
\hline 1 & 2 & 3 & 4 & 5 & 6 & 7 & 8 & 9 & 10 & 11 & 12 \\
\hline 21.5 & 35.2 & 13.0 & 8.6 & 5.7 & 3.9 & 2.8 & 2.0 & 2.2 & 1.5 & 0.8 & 0.2 \\
\hline 13 & 14 & 15 & 16 & 17 & 18 & 19 & 20 & 21 & 22 & 23 & 24 \\
\hline 0.5 & 0.2 & 0.2 & 0.2 & 0.2 & 0.2 & 0.2 & 0.2 & 0.2 & 0.2 & 0.2 & 0.1 \\
\hline
\end{tabular}

\section{STORM DURATION: 18 HOURS}

$A R I \leq 30$ YEARS

\begin{tabular}{|c|c|c|c|c|c|c|c|c|c|c|c|c|}
\hline Period of design storm, $\mathrm{P}$ & 1 & 2 & 3 & 4 & 5 & 6 & 7 & 8 & 9 & 10 & 11 & 12 \\
\hline$\%$ of total rainfall & 19.7 & 58.8 & 10.0 & 5.0 & 3.1 & 1.7 & 0.1 & 0.1 & 0.1 & 0.1 & 0.1 & 0.1 \\
\hline Period of design storm, $\mathrm{P}$ & 13 & 14 & 15 & 16 & 17 & 18 & & & & & & \\
\hline$\%$ of total rainfall & 0.1 & 0.6 & 0.1 & 0.1 & 0.1 & 0.1 & & & & & & \\
\hline
\end{tabular}

ARI > 30 YEARS

\begin{tabular}{|c|c|c|c|c|c|c|c|c|c|c|c|c|}
\hline Period of design storm, $\mathrm{P}$ & 1 & 2 & 3 & 4 & 5 & 6 & 7 & 8 & 9 & 10 & 11 & 12 \\
\hline$\%$ of total rainfall & 18.9 & 55.2 & 9.8 & 5.0 & 3.2 & 1.8 & 0.3 & 0.3 & 0.3 & 0.3 & 0.4 & 0.4 \\
\hline Period of design storm, $\mathrm{P}$ & 13 & 14 & 15 & 16 & 17 & 18 & & & & & & \\
\hline$\%$ of total rainfall & 0.3 & 2.2 & 0.4 & 0.4 & 0.4 & 0.4 & & & & & & \\
\hline
\end{tabular}

\section{STORM DURATION: 24 HOURS}

ARI $\leq 30$ YEARS

\begin{tabular}{|c|c|c|c|c|c|c|c|c|c|c|c|c|}
\hline Period of design storm, $\mathrm{P}$ & 1 & 2 & 3 & 4 & 5 & 6 & 7 & 8 & 9 & 10 & 11 & 12 \\
\hline$\%$ of total rainfall & 18.2 & 56.0 & 11.0 & 0.8 & 0.6 & 0.6 & 0.5 & 0.5 & 0.4 & 0.5 & 0.5 & 0.5 \\
\hline Period of design storm, $\mathrm{P}$ & 13 & 14 & 15 & 16 & 17 & 18 & 19 & 20 & 21 & 22 & 23 & 24 \\
\hline$\%$ of total rainfall & 0.5 & 0.5 & 0.5 & 0.5 & 0.5 & 0.5 & 0.5 & 0.5 & 0.5 & 2.8 & 1.6 & 1.0 \\
\hline
\end{tabular}


ARI > 30 YEARS

\begin{tabular}{|l|c|c|c|c|c|c|c|c|c|c|c|c|}
\hline Period of design storm, P & 1 & 2 & 3 & 4 & 5 & 6 & 7 & 8 & 9 & 10 & 11 & 12 \\
\hline \% of total rainfall & 17.5 & 52.7 & 10.8 & 0.8 & 0.6 & 0.8 & 0.7 & 0.7 & 0.7 & 0.7 & 0.7 & 0.7 \\
\hline Period of design storm, P & 13 & 14 & 15 & 16 & 17 & 18 & 19 & 20 & 21 & 22 & 23 & 24 \\
\hline \% of total rainfall & 0.7 & 0.8 & 0.8 & 0.8 & 0.8 & 0.8 & 0.8 & 0.8 & 0.9 & 2.8 & 1.6 & 1.0 \\
\hline
\end{tabular}

\section{STORM DURATION: 30 HOURS}

\section{ARI $\leq 30$ YEARS}

\begin{tabular}{|l|c|c|c|c|c|c|c|c|c|c|c|c|}
\hline Period of design storm, $\mathrm{P}$ & 1 & 2 & 3 & 4 & 5 & 6 & 7 & 8 & 9 & 10 & 11 & 12 \\
\cline { 1 - 7 } \% of total rainfall & 62.8 & 17.0 & 3.0 & 0.9 & 0.9 & 0.9 & 0.9 & 0.9 & 0.9 & 0.9 & 0.9 & 1.1 \\
\hline Period of design storm, P & 13 & 14 & 15 & &
\end{tabular}

ARI > 30 YEARS

\begin{tabular}{|c|c|c|c|c|c|c|c|c|c|c|c|c|}
\hline Period of design storm, $\mathrm{P}$ & 1 & 2 & 3 & 4 & 5 & 6 & 7 & 8 & 9 & 10 & 11 & 12 \\
\hline$\%$ of total rainfall & 59.0 & 16.3 & 3.0 & 1.2 & 1.3 & 1.3 & 1.3 & 1.3 & 1.4 & 1.4 & 1.4 & 1.7 \\
\hline Period of design storm, $\mathrm{P}$ & 13 & 14 & 15 & & & & & & & & & \\
\hline$\%$ of total rainfall & 5.6 & 2.4 & 1.4 & & & & & & & & & \\
\hline
\end{tabular}

STORM DURATION: 36 HOURS

\section{ARI $\leq 30$ YEARS}

\begin{tabular}{|c|c|c|c|c|c|c|c|c|c|c|c|c|}
\hline Period of design storm, $\mathrm{P}$ & 1 & 2 & 3 & 4 & 5 & 6 & 7 & 8 & 9 & 10 & 11 & 12 \\
\hline$\%$ of total rainfall & 62.0 & 16.7 & 3.0 & 0.7 & 0.7 & 0.7 & 0.7 & 0.7 & 0.7 & 0.7 & 0.7 & 0.8 \\
\hline Period of design storm, $\mathrm{P}$ & 13 & 14 & 15 & 16 & 17 & 18 & & & & & & \\
\hline$\%$ of total rainfall & 5.9 & 2.7 & 1.3 & 0.7 & 0.7 & 0.6 & & & & & & \\
\hline
\end{tabular}

ARI > 30 YEARS

\begin{tabular}{|c|c|c|c|c|c|c|c|c|c|c|c|c|}
\hline Period of design storm, $\mathrm{P}$ & 1 & 2 & 3 & 4 & 5 & 6 & 7 & 8 & 9 & 10 & 11 & 12 \\
\hline$\%$ of total rainfall & 58.2 & 16.1 & 3.0 & 1.0 & 1.0 & 1.0 & 1.0 & 1.1 & 1.1 & 1.1 & 1.1 & 1.1 \\
\hline Period of design storm, $\mathrm{P}$ & 13 & 14 & 15 & 16 & 17 & 18 & & & & & & \\
\hline$\%$ of total rainfall & 5.8 & 2.7 & 1.3 & 1.1 & 1.1 & 1.2 & & & & & & \\
\hline
\end{tabular}

\section{STORM DURATION: 48 HOURS}

\section{ARI $\leq 30$ YEARS}

\begin{tabular}{|l|c|c|c|c|c|c|c|c|c|c|c|c|}
\hline Period of design storm, P & 1 & 2 & 3 & 4 & 5 & 6 & 7 & 8 & 9 & 10 & 11 & 12 \\
\hline \% of total rainfall & 61.6 & 16.6 & 2.9 & 0.4 & 0.4 & 0.4 & 0.4 & 0.4 & 0.4 & 0.4 & 0.4 & 1.6 \\
\hline Period of design storm, P & 13 & 14 & 15 & 16 & 17 & 18 & 19 & 20 & 21 & 22 & 23 & 24 \\
\hline \% of total rainfall & 3.2 & 0.8 & 0.4 & 0.4 & 0.4 & 0.4 & 8.0 & 0.1 & 0.1 & 0.1 & 0.1 & 0.1 \\
\hline
\end{tabular}

\section{ARI > 30 YEARS}

\begin{tabular}{|l|c|c|c|c|c|c|c|c|c|c|c|c|}
\hline Period of design storm, P & 1 & 2 & 3 & 4 & 5 & 6 & 7 & 8 & 9 & 10 & 11 & 12 \\
\hline \% of total rainfall & 57.9 & 16.0 & 3.0 & 0.4 & 0.7 & 0.7 & 0.7 & 0.7 & 0.7 & 0.7 & 0.8 & 1.6 \\
\hline Period of design storm, P & 13 & 14 & 15 & 16 & 17 & 18 & 19 & 20 & 21 & 22 & 23 & 24 \\
\hline \% of total rainfall & 3.2 & 0.8 & 0.8 & 0.8 & 0.8 & 0.8 & 7.8 & 0.3 & 0.2 & 0.2 & 0.2 & 0.2 \\
\hline
\end{tabular}

\section{STORM DURATION: 72 HOURS}

\section{ARI $\leq 30$ YEARS}

\begin{tabular}{|l|c|c|c|c|c|c|c|c|c|c|c|c|}
\hline Period of design storm, P & 1 & 2 & 3 & 4 & 5 & 6 & 7 & 8 & 9 & 10 & 11 & 12 \\
\hline \% of total rainfall & 55.4 & 14.6 & 0.5 & 0.5 & 0.5 & 0.5 & 10.8 & 1.8 & 0.6 & 0.6 & 0.6 & 0.6 \\
\hline Period of design storm, P & 13 & 14 & 15 & 16 & 17 & 18 & & & &
\end{tabular}


ARI > 30 YEARS

\begin{tabular}{|c|c|c|c|c|c|c|c|c|c|c|c|c|}
\hline Period of design storm, $\mathrm{P}$ & 1 & 2 & 3 & 4 & 5 & 6 & 7 & 8 & 9 & 10 & 11 & 12 \\
\hline$\%$ of total rainfall & 52.1 & 14.0 & 0.8 & 0.8 & 0.8 & 0.8 & 10.6 & 1.9 & 0.9 & 0.9 & 0.9 & 0.9 \\
\hline Period of design storm, $\mathrm{P}$ & 13 & 14 & 15 & 16 & 17 & 18 & & & & & & \\
\hline$\%$ of total rainfall & 3.5 & 1.4 & 0.9 & 0.9 & 1.0 & 6.9 & & & & & & \\
\hline
\end{tabular}

As these factored percentages did not add to $100 \%$, the ARR87 procedure was used to re-proportion the individual percentage so that the total percentage for a particular pattern will be equal to 100 . This was done by maintaining the factored percentage of higher ranking positions (e.g. ranks 1, 2, 3 etc.) and redistribute the surplus or deficit to the remaining periods of the pattern. For this study, the factored percentage values for the highest $1 / 3$ of the ranks (rank 1, 2, $3 \ldots$ ) were maintained with total discrepancies equally distributed to the remaining $2 / 3$ periods. The temporal patterns for ARI $>30$ years with ranking positions similar to those of ARI $\leq 30$ years, are presented in Table 4 .

\subsection{CONCLUSION}

In flood estimation, short and long duration rainfall data are both required for different sizes of catchments to determine and locate the flood producing critical storms. Design temporal patterns with different durations are therefore also required for distributing the storm rainfall in flood calculations. Patterns for a large number of durations with reasonably short time intervals are needed by designers to reduce the need for interpolation and to maintain the accuracy in obtaining the peak of the hydrograph.

An average temporal pattern is generally used which is derived from a large number of rainfall stations in a region. Temporal patterns have been developed in Hydrological Procedure No. 1 by simple averaging of storm rainfall and these have been used in flood estimation for catchments in Peninsular Malaysia. Long-time intervals were used in these patterns and these may result in calculated discharge missing the peak of the hydrograph. There are only a limited number of patterns available in the Procedure and interpolation is required to obtain intermediate patterns. As pluviograph rainfall data have been increased by a large amount for the past 20 years, it is the aim of this study to derive design rainfall temporal patterns for Upper Klang Catchment using the local data and employing the widely accepted Method of Average Variability as used in ARR87.

In general, flood estimations are based on design event approach as recommended in ARR87. This method needs the formulation of a design rainfall event and use of a rainfall runoff model to convert the design rainfall event into the corresponding design flow. The design rainfall event is specified by the rainfall duration, average rainfall intensity of a particular average recurrence interval (ARI) and the rainfall temporal pattern. The main assumption of the design event approach is that a rainfall intensity of a particular ARI can be converted to a streamflow hydrograph peak of the same ARI using critical duration and representative values of other input variables to the rainfall runoff model such as initial loss. The ARR87 adopted such a concept for deriving the rainfall temporal patterns for use in Australia. The patterns derived are assumed to provide the conversion of a $Y$ year rainfall to a design flood of the same ARI.

In this study, rainfall temporal patterns for the Upper Klang were derived for rainfall durations from 10 minutes to 72 hours and for time intervals from 5 minutes to 4 hours.
The patterns presented in this study demonstrate the use of Average Variability Method in deriving design rainfall temporal patterns for data of the Klang Catchment and the patterns derived can be used for design flood estimations for catchments in the same general region.

\subsection{ACKNOWLEDGEMENT}

The permission of Drainage and Irrigation Department to use the data for this study is gratefully acknowledged.

\section{REFERENCES}

[1] Ataur, R. and Mazharul, I. (2006). Investigation of Design Rainfall Temporal Patterns in the Gold Coast Region of Queensland, Institution of Engineers Australia.

[2] Askew, A. J. (1975). Variations in Estimates of Design Flood, Institution of Engineers Australia, Hydrology Symposium, New South Wales, Australia. Institution of Engineers Australia National Conference Publication, 75(3), 26-30.

[3] Ball J. E. (1994). The Influence of Storm Temporal Patterns on Catchment Response. Journal of Hydrology, 158(3-4), 285-303.

[4] Cordery, I., Pilgrim, D. H. and Rowbottom, I. A. (1984). Time Patterns of Rainfall for Estimating Design Floods on a Frequency Basis. Water Science \& Technology, 16, 155-165.

[5] Drainage and Irrigation Department (1982). Design Rainstorm for Peninsular Malaysia, Hydrological Procedure No 1.

[6] Faridah, O., Akbari, A. and Samah, A. A. (2011). Spatial Rainfall Analysis for an Urbanized Tropical River Basin. International Journal of the Physical Sciences, 6(20), 4861-4868.

[7] Hershfield, D. M. (1962). Extreme Rainfall Relationships. Journal of the Hydraulics Division, 88(HY6), 73-92.

[8] Huff, F. A. (1967). Time Distribution of Rainfall in Heavy Storms. Water Resources Research, 3(4), 1007-1019.

[9] Institution of Engineers, Australia (1987). Australian Rainfall and Runoff.

[10] Keifer, C. J. and Chu, H. H. (1957). Synthetic Storm Pattern for Drainage Design. Journal of the Hydraulics Division, 83(HY4), $1-25$.

[11] Milston, A. K. (1979). The Influence of Temporal Patterns of Design Rainfall on Peak Flood Discharge. Master's Thesis, University Of New South Wales.

[12] National Oceanic and Atmospheric Administration (2014). Precipitation Frequency Atlas of the United States, Vol. 6 Version 2.3, California.

[13] Nathan, R. J. and Weinmann, P. E. (2004). An Improved Framework for the Characterization of Extreme Flood and the Assessment of Dam Safety. Hydrology: Science \& Practice for the 21 st Century, British Hydrological Society, London, 186-193. 


\section{DESIGN RAINFALL TEMPORAL PATTERNS FOR UPPER KLANG CATCHMENT}

[14] Pilgrim, D. H. and Cordery, I. (1975). Rainfall Temporal Patterns for Design Flood Estimation. Journal of the Hydraulics Division, 101 (HY1), 81-95.

[15] Pilgrim, D. H., Cordery, I., and French, R. (1969). Temporal Patterns of Design Rainfall for Sydney. Civ Engr Trans Inst Engrs Aust, CE11, 9-14.

[16] Rahman, A., Islam, M., Rahman, K., Khan, S. and Shrestha, S. (2006). Investigation of Design Rainfall Temporal Patterns in the Gold Coast Region of Queensland. Australasian Journal of Water Resources, 10(1), 49-61.
[17] Rahman, A., Weinmann, P. E., Hoang, T. M. T and Laurenson, E. M. (2002). Monte Carlo Simulation of Flood Frequency Curves from Rainfall. Journal of Hydrology, 256(3-4), 196-210.

[18] Touhid, B., Ataur, R. and Scott, A. (2010). Derivation of Design Rainfall Temporal Pattern in Australia's Gold Coast Region, Queensland University.

[19] U.S. Dept. of Agriculture, Soil Conservation Services (1973). A Method for Estimating Volume and Rate of Runoff in Small Watersheds. TP-149, Washington D. C.

[20] Yen, B. C. and Chow, V. T. (1980). Design Hydrographs for Small Drainage Structures. J. Am. Soc. Civ. Eng., 106(HY6), 1055-1076.

\section{PROFILES}

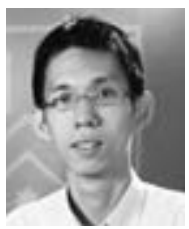

DAVID HONG JER LANG is currently a lecturer of Taylor's University, Malaysia. He received his B. Sc Degree in Computer Science from Nottingham University in 2005 and the Ph.D. degree from Monash University in 2010. He is author and co-author of several Association for Computing Machinery/Institution of Electrical and Electronic Engineers (ACM/IEEE) conference papers and is also the author of several papers in automatic wrapper design published in computer science journals and is the co-author of the book "Hydrological Analysis and Design: An approach based on Malaysian Rainfall and Runoff”. David Hong is listed in Who's Who in the World. E-mail address: jerlang.hong@taylors.edu.my

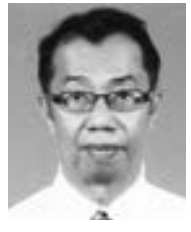

IR. AZMI MD JAFRI is a professional engineer registered with Board of Engineers Malaysia. Currently he is a hydrologist with ZHL Engineers Sdn Bhd. He obtained Bachelor and Masters in Civil Engineeng from University Teknologi MARA and a post graduate Diploma in Hydrologic Engineering from IHE Delft the Netherlands. During his time at the Department Irrigation and Drainage Malaysia he was involved in research, operational and application aspects of hydrological activities of the department. Email address: azmijafri@gmail.com

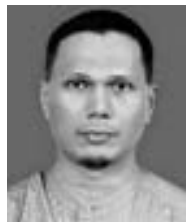

IZIHAN BIN IBRAHIM is a Professional Civil Engineer registered with the Board of Engineers Malaysia. He holds a Bachelor of Science (Summa Cum Laude) in Civil Engineering (1986; USA), and a Master of Science (with Distinction) in Engineering Hydrology (1989; Imperial College of Science, Technology and Medicine, London, U.K). Izihan is presently an Academic Fellow at the Department of Civil Engineering, Kulliyyah of Engineering, International Islamic University Malaysia. He is also the Managing Director of Rho-1 Consultants, an engineering consultancy firm dedicated in providing specialist services through its continuous research and development efforts in the fields of hydrology and hydraulics. Over the past 30 years, Izihan has extensive experience as a numerical/computer modeller utilizing established models such as MIKE11, MIKE Flood, MOUSE, WMS, SWAT, HEC-HMS, HEC-RAS, XP-SWMM, PCSWMM, MOHID Land/Studio. He has successfully conducted a number of studies encompassing EIAs, hydrologic-hydraulic analyses and modelling of rivers and drainage systems, as well as design projects for a wide range of applications. E-mail: izihan@gmail.com, izihan@iium.edu.my

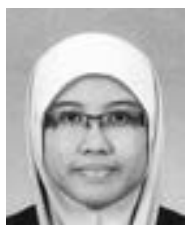

SUZANA BINTI SHAFIE obtained her Bachelor Degree in Civil Engineering from University Teknologi Malaysia (UTM) in 2007. Suzana joined G\&P Water and Maritime Sdn. Bhd. in 2008 and she is now Associate and Chief Hydrologist of the firm. She is actively involved in flood and yield studies and currently her major role is on flood and low river flow and reservoir operation projects mainly on the research prospects. Email address: suzana_peace@yahoo.com

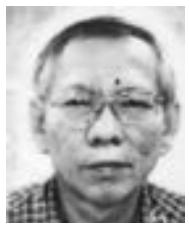

HONG KEE AN is presently a Consultant in Hydrology and Water Resources and he worked as a hydrologist, water resources planner and modeler for various water supply projects in Malaysia. He received his B.Sc. degree in Agricultural Engineering from National Taiwan University in 1971 and the M. Eng. degree in Water Science from Asian Institute of Technology in 1973. He is the author of several papers published in the journal and bulletins of the Institution of Engineers, Malaysia and Malaysian Water Work Association and the books" A Guide to Flood and Yield Estimation" and "Hydrlogical Analysis and Design: An approach based on Malaysian Rainfall and Runoff". He is a Fellow of the Institution of Engineers, Malaysia and is listed in Who's Who in Engineering published by the American Association of Engineering Societies. E-mail address: keeanhong@yahoo.co.uk

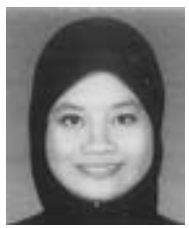

IRENA BINTI NAUBI received her Bachelor's Degree and Master's Degree from Universiti Teknologi Malaysia (UTM). She is currently working as an Engineer in G\&P Water \& Maritime Sdn. Bhd. and involved in hydrology projects such as Development of Hydrological Procedure and Dam Operational Studies. Email address: irena.naubi@gmail.com 